JANUSZ ZIMNY

KATARZYNA MAKOWSKA

ALEKSANDRA ZIMNY

ANDRZEJ CZAPLICKI

SYLWIA OLESZCZUK

Instytut Hodowli i Aklimatyzacji Roślin — Państwowy Instytut Badawczy, Radzików

Kierownik Tematu: prof. dr hab. Janusz Zimny Zakład Biotechnologii i Cytogenetyki Roślin, Instytut

Hodowli i Aklimatyzacji — PIB, Radzików, 05-870 Błonie, tel. 22 7334520, e-mail: j.zimny@ihar.edu.pl

Prace zostaty wykonane $w$ ramach badań podstawowych na rzecz postępu biologicznego w produkcji roślinnej na podstawie decyzji Ministra Rolnictwa i Rozwoju Wsi nr HOR.hn.802.19.2018, Zadanie 85.

\title{
Badanie reakcji mikrospor żyta na stres i warunki kultury in vitro
}

The study on rye microspore reaction to stress and in vitro culture conditions

Słowa kluczowe: androgeneza, in vitro, mikrospory, podwojone haploidy, regeneracja, żyto

Celem zadania jest: określenie wpływu zastosowanych stresów przeprogramowania mikrospor i warunków kultury (rodzaj pożywki) na indukowanie androgenezy, jakościową (rośliny zielone i albinotyczne) i ilościową regenerację roślin oraz określenie alternatywnego do kolchicyny sposobu podwajania liczby chromosomów wśród otrzymanych regenerantów. Zadanie obejmowało 4 zagadnienia.

\section{ZAGADNIENIE 1}

Analiza wpływu różnych czynników stresowych na indukcję androgenezy. Celem badań było sprawdzenie zróżnicowania reakcji mikrospor na 9 rodzajów stresu przeprogramowujących ich rozwój gametofitowy w kierunku sporofitowego

Potwierdzono znaczenie odpowiednio dobranego rodzaju stresu dla efektywności indukowania androgenezy w kulturach pylników żyta. Linie 5 i 8 zareagowały wyraźnie lepiej w porównaniu do linii 6 , niezależnie od zastosowanego stresu. Wyraźnie źle reagowały pylniki wszystkich genotypów na stres z zastosowaniem HNA w połączeniu z BAP i 2,4-D. Najlepsze wyniki dla linii 5 i 8 otrzymano w wyniku działania stresu 
$4^{\circ} \mathrm{C} / 21$ dni oraz chłodzenia pędów z kłosami i ich prekultury w roztworze mannitolu przez $7 \mathrm{dni} / 4^{\circ} \mathrm{C}$. Obok chłodu istotne znaczenie miało zastosowanie, jako prekultury mannitolu lub pożywki SolA (Corondaro i in., 2005). Uzyskane dane wskazują, że te stresy były najbardziej uniwersalne.

Różna reakcja na zastosowane stresy stwarza konieczność zbadania i dostosowania stresu do konkretnego genotypu. Uniwersalnym typem stresu jest chłodzenie pędów z kłosami przez 21 dni oraz chłodzenie pędów z kłosami w połączeniu prekulturą pylników w roztworze mannitolu lub pożywce SolA.

\section{ZAGADNIENIE 2}

Zbadanie wpływu czynników stresowych i składu pożywek na zjawisko albinizmu regenerantów. Celem prac było określenie możliwości ograniczenia zjawiska albinizmu poprzez dobór stresu inicjującego androgenezę oraz modyfikację składu pożywek zastosowanych na etapie indukcji procesu

Poziom regeneracji wahał się $\mathrm{w}$ granicach od 0 do ponad 20 roślin (zielone + albinotyczne) na 100 wyłożonych pylników, w zależności od genotypu, rodzaju stresu i stosowanej pożywki. Wytypowano genotypy o wysokim potencjale regeneracyjnym (linie 5 i 8) oraz takie, dla których możliwe było otrzymanie kilku roślin, tylko w niektórych kombinacjach stresowych. Poziom albinizmu wahał się od 0 do 10,5\%, w zależności od rodzaju zastosowanego stresu i pożywki. Najwyższy odsetek roślin bezchlorofilowych, otrzymano dla stresów chłodu i chłodu + prekultura w mannitolu w linii 5, zwłaszcza w kombinacji z pożywką KBP (Kumlehn i in. 2006). Dla linii 8, po zastosowaniu stresu chłodu + prekultura na pożywce SolA regeneracja albinosów była na zbliżonym poziomie ok. 3,8\% na obu badanych pożywkach (190-2 (Pauk i in. 1991) i KBP). Zastosowanie pożywki KBP przyniosło wzrost wydajności regeneracji roślin, ale nie wpłynęło na zredukowanie zjawiska albinizmu.

Genotyp ma kluczowe znaczenie dla efektywności procesu androgenezy, regeneracji roślin oraz poziomu albinizmu, niemniej jednak poprzez odpowiedni dobór warunków zewnętrznych możliwe jest wpływanie na powyższe parametry. Rodzaj stresu ma wpływ na liczbę roślin albinotycznych u konkretnych genotypów. Pożywka KBP istotnie poprawia wydajność regeneracji roślin, dla niektórych genotypów i zastosowanych stresów.

\section{ZAGADNIENIE 3}

Zbadanie wpływu ustalonego stresu, warunków kultury i systemu podwajania liczby chromosomów na liczbę regenerowanych zielonych roślin. Morfologiczna i cytometryczna charakterystyka oraz ocena poziomu płodności otrzymanych regenerantów

Odsetek osobników diploidalnych po analizach cytometrycznych wynosił $72 \%$. Nie uwidocznił się związek pomiędzy częstotliwością spontanicznej diploidyzacji a genotypem. Różnice w ogólnym pokroju, intensywności wzrostu i rozwoju pomiędzy liniami 
w obrębie genotypu, obserwowano niezależnie od zastosowanego czynnika stresowego. Występowała duża rozpiętość w liczbie wytworzonych pędów, długości źdźbła oraz długości kłosów. Około 5\% linii odznaczało się zróżnicowaniem morfologicznym obejmującym min. skrócenie źdźbła, sektorialne zmiany w budowie kłosa, zaburzenie pokroju, trudności z wykłoszeniem, spowolniony wzrost, degenerację pylników, wysoki udział pyłku sterylnego. Płodne rośliny stanowiły od $16 \%$ do $75 \%$ dla różnych linii. Od 30\% do 60\% osobników wykazywało częściową płodność. Często ziarniaki były pomarszczone i mniejsze w porównaniu do tych z roślin donorowych, a efektywność ich zawiązywania wynosiła od 1 do 47/na roślinę. Liczba nasion w kłosie była wyższa w wyniku swobodnego przypylenia.

Cytometryczna ocena diploidyzacji regenerantów wykonana wg Galbraith i in. (1983) nie przekłada się na płodność ocenioną na etapie pełnej dojrzałości. Płodność regeneratów i efektywność zawiązywania ziarniaków nie są związane z rodzajem stresu indukującego androgenezę.

\section{ZAGADNIENIE 4}

Ocena wpływu herbicydów antymitotycznych na podwajanie liczby chromosomów w kulturach in vitro - badania wstępne (drugi rok). Badania obejmowały przetestowanie wytypowanych $w$ roku ubieglym inhibitorów mitozy na przeżywalność androgenicznych roślin

Odnotowano wysoką śmiertelność wśród młodszych roślin $(\mathrm{ok} 2 \mathrm{~cm})$ powodowaną toksycznym działaniem antymitotyków, tj. $5 \mu \mathrm{M}$ oryzaliny $-\mathrm{O}_{5}$ oraz $10 \mu \mathrm{M}$ trifluraliny - $\mathrm{T}_{10}$. Negatywny wpływ stosowanych związków w tej grupie eksplantatów objawiał się żółknięciem, brązowieniem tkanek, w wyniku czego dalszy rozwój roślin ulegał częściowemu spowolnieniu lub zahamowaniu - śmiertelność regenerantów wzrastała wraz $\mathrm{z}$ wydłużeniem czasu ekspozycji. Po zastosowaniu $\mathrm{T}_{10}$ zamarło $42,5 \%$ eksplantantów oraz prawie $50 \% \mathrm{w}$ przypadku $\mathrm{O}_{5}$, podczas gdy w kontroli zaledwie $7 \%$. Natomiast $\mathrm{w}$ grupie starszych eksplantatów - tj. ukorzenionych roślin, nie znaleziono powiązania między liczbą regenerantów, które przeżyły/wypadły po wysadzeniu do gleby, a rodzajem antymitotyku i czasem jego ekspozycji. Na etapie wysadzania do gleby obserwowano zamieranie głównie roślin rachitycznych, obecnych również w badaniu kontrolnym.

Przeżywalność eksplantatów poddawanych działaniu antymitotyków w formie herbicydów na pożywkach $\mathrm{w}$ warunkach in vitro jest zależna od ich stadium rozwojowego. Oryzalina wykazuje silniejsze działanie fitotoksyczne w porównaniu do trifluraliny na etapie małych roślin. Spadek przeżywalności regenerantów wysadzonych do gleby nie jest spowodowany działaniem substancji antymitotycznych.

\section{LITERATURA}

Coronado M. J., Hensel G., Broeders S., Otto I., Kumlehn J. 2005. Immature pollen-derived doubled haploid formation in barley cv. Golden Promise as a tool for transgene recombination. APP. 27 (4): 591 - 599. 
Galbraith D. W., Harkins K. R., Maddox J. M., Ayres N. M., Sharma D. P., Firoozabady E. 1983. Rapid flow cytometric analysis of the cell cycle in intact plant tissues. Science 220: $1049-1051$.

Kumlehn J., Serazetdinova, L., Hensel G., Becker D., Lörz H. 2006. Genetic transformation of barley (Hordeum vulgare L.) via infection of androgenetic pollen cultures with Agrobacterium tumefaciens. Plant Biotechnology Journal 4: $251-261$.

Pauk J., Manninen O., Mattila I., Salo Y., Puli S. 1991. In vitro androgenesis of triticale in isolated microspore culture. Plant Breed. 107: $18-27$. 